\title{
The Gospel of Matthew as a Literary Argument
}

\author{
Mika Hietanen
}

Published online: 9 October 2010

(C) The Author(s) 2010. This article is published with open access at Springerlink.com

\begin{abstract}
Through an argumentation analysis can one show how it is feasible to view a narrative religious text such as the Gospel of Matthew as a literary argument. The Gospel is not just "good news" but an elaborate argument for the standpoint that Jesus is the Son of God, the Messiah. It is shown why an argumentation analysis needs to be supplemented with a pragmatic literary analysis in order to describe how the evangelist presents his story so as to reach his argumentative objective. The analysis also shows why in the case of historical religious literary texts, certain demands are put on the analyst that are not normally present.
\end{abstract}

Keywords Argumentation analysis - Pragmatic analysis of argumentation · Literary arguments - Christian argumentation - The Gospel of Matthew - The New testament $\cdot$ Analysis of religious texts

\section{Introduction}

Bertrand Russell once said, "I do not think that the real reason why people accept religion has anything to do with argumentation. They accept religion on emotional grounds" (Russell 1927). In the same speech Russell gives detailed arguments as to why he himself is not a Christian. Interestingly, Russell's argumentation is problematic since his portrayal of the basics of Christian faith is quite different from the picture we get from the Gospels. For instance, to believe that "Christ was the best and wisest of men" (according to Russell one of the basic Christian dogmas) is not at all the same as to confess Jesus to be "the Messiah, the Son of the living God" (Peter's climactic statement in Matt. 16:16). Even though the evangelists were not yet concerned with apologetics proper, it would be interesting to explore what a focus on argumentation

\footnotetext{
M. Hietanen $(\bowtie)$

University of Amsterdam, Amsterdam, The Netherlands

e-mail: mika.hietanen@rhetor.fi
} 
can yield concerning the Gospels, to show what arguments are put forth in support of the message. After all, regardless of what role emotions play when people accept or reject religion, in both cases people often use argumentation to justify their choice.

As literature, the Gospels represent a mixture of different genres. On the one hand, they purport to present the circumstances of Jesus' birth, ministry, and death. On the other hand, they express the conviction that Jesus from Nazareth is the divine saviour. That this conviction permeates the New testament is elementary, but one traditional view is to consider the Gospels primarily from the point of view of "good news". ${ }^{1}$ This line of thought is misleading. We must not approach the Christian Gospels as non-persuasive texts, void of rhetorical practises. In fact, the Gospels convey the result of a complex process of reflection and revision of the Jesustradition. If we want to understand the Gospels as news, they are a very special kind of "news", then, presented in a certain way and with a certain purpose, a part of which is persuasion. I propose that a pragmatic literary analysis with an argumentation analytical backdrop can help identify and describe this purpose. At the same time I illustrate how a pragmatic and argumentation analytical approach in spite of some difficulties can be put to fruitful use on a historical religious text.

The argumentative aspect is important if we want to understand how readers and hearers are influenced by the Gospel-message. Narrative and rhetorical analyses have done much to help us understand this process, but the aspect of argumentation needs to be explored further.

I divide this study into two parts. First (in Sect. 2), I place the text in its historical context and take a peek at how narrative criticism and rhetorical criticism deal with argumentation in the Gospel of Matthew. I then show how an argumentation analysis can provide a clearer framework for the aspect of argumentation in the Gospel of Matthew. I also take a look at a short passage as a test-case, the virgin conception.

In the second part (Sect. 3), then, I focus on how Matthew designs the literary details of his text in order for it to function as an argument. Only through a pragmatic literary argumentation analysis can such features be described in a way that makes an inter-subjective evaluation possible, i.e. in a way that makes it easier for others to follow the train of thought of the analyst. An analysis of the story of the so-called Gadarene exorcism illustrates how a pragmatic literary argumentation analysis can be applied on a historical religious text and how such an analysis gives information that other methods do not yield.

\section{Analysing Matthew as an Argument}

\subsection{Matthew's Argument in its Historical Context}

I turn to Matthew because it has two features that make it a good candidate among the Gospels for an argumentation analysis. First, the background of a disagreement

\footnotetext{
1 For instance, Dickson (2005) argues that in antiquity "gospel" always connoted a message that was news to the hearer. He further refers to Liftin (1994, 195-197) who points out that since euangel- [the main part of the Greek verb for "evangelize"] in classical usage connoted "report" rather than "persuasion", it was of little significance in the rhetorical practises and literature of the period.
} 
between the status quo (Judaism) and the new Jesus-movement (Christianity) is very clear in Matthew. Jesus' clashes with the official representatives of the Jewish religion and nation are clearly described. Second, It is a carefully constructed Gospel. In comparison with the other synoptists, ${ }^{2}$ Matthew "impresses by the care and literary artistry involved in its composition" (France 1990, 21). Kennedy (1984, 44) has noted that "Matthew felt an exigence to supply a Gospel which would be intellectually satisfying in a way that Mark's Gospel was not." Thus Matthew lends itself more easily to an argumentation analysis. This is not to say that arguments are not present in the other Gospels, including John (cf. John 20:31).

Regarding the question of the precise nature of the dispute- the one that gives rise to argumentation - we must note the issue of a dual audience. In a sense we have two stories in Matthew-Luz describes Matthew as a "Jesus story with a double meaning" (Luz 2005, 14). First, we have the core of the Gospel-story: the main elements of Jesus' birth, teachings, ministry, life, and death. These are common for all evangelists. Second, we have the particular form of the story as written by Matthew. There is a reason why Matthew wanted to write another version in addition to Mark. For the Jewish Christian communities in Syria in the period after $70 \mathrm{CE}$, Matthew needs to re-interpret the Gospel-story especially with regard to Israel's place in it and with regard to a mission outside of Israel (see Luz 2005, 3-17). ${ }^{3}$

My focus is here on the main story and not on the specific goal of Matthew in distinction from the other synoptists. I explore the perspective of the Gospel as a whole as presenting an argument. Also, analysing the core of the Gospel-message is more interesting when we want to describe what aspects of the Gospel contribute to make the story convincing for later generations up to this day.

The evangelists uphold a whole set of standpoints that go against the status quo. These standpoints, the Christian message, the Gospel, are proclaimed by Jesus and other characters in the Gospels. We here seem to have all the elements of argumentation: standpoints supported by arguments in a context of conflict and persuasion. It can, however, be argued that since the evangelists primarily wrote to believers, they had no case to argue. But since the Gospels are the only accounts of the Jesus-story, it is unlikely that the evangelists would not have realized the importance of presenting the story in a way that is both trustworthy and compelling. From early on these texts have served both as the cardinal pieces of devotional and instructional literature for believers as well as the literary foundation for carrying out the Great Commission (Matt. 28:16-20) to non-believers. Even in the former

\footnotetext{
2 The Gospels of Matthew, Luke, and Mark are the Synoptics and their authors the synoptists.

3 Matthew is written in Greek, probably some time between 70 and 95 CE, in a larger Syrian city (Luz 1985, 73-76). The apostle Matthew is traditionally accredited as the author, but this cannot be confirmed (Luz 1985, 76-77). The most common theory is that the author, whom I shall call Matthew (since the "authors" build upon earlier written and oral sources and the Gospels are the result of a compilation spanning decades, they should be seen as editors who give voice to different traditions) made use of two sources: the Gospel of Mark and the so-called Q-source (the fact that both Matthew and Luke share much material not found in their source, Mark, has generated a hypothesis of a second common source, Q"die Logien-Quelle"-a collection of sayings of Jesus). No original manuscript exist for any of the twenty-seven New testament texts; the oldest extant fragments (of hand-written copies) are from the second century.
} 
function the Gospels have an argumentative function since also believers seek arguments in support for their faith.

Before I turn to a specific argumentation analysis, it is useful to take a look at Matthew's argumentation from the perspective of two well-known approaches within New testament exegesis that both overlap with an argumentation analysis: narrative criticism and rhetorical criticism. As regards specifically argumentation analytical studies, I am not aware of any studies of the Gospels as a whole. ${ }^{4}$

\subsection{Matthew's Argument and Narrative Criticism}

In a narrative analysis one approaches the Gospel as a unified narrative where action, characters, and story-line are organised by means of a coherent plot. One distinguishes between two parts in a narrative, story and discourse (Chatman 1978, 19-27); the story is the life and works of Jesus and the discourse is the way in which this story is told.

David B. Howell describes a narrative analysis of the Gospels as a study of "how readers of the Gospel are to appropriate and involve themselves in the story and teaching of the Gospel." Pertinent questions are: "Are literary techniques used which help structure a reader's response to the story and its message? If so, how do they function?" (Howell 1990, 17). Many observations made on the basis of a narrative analysis are relevant for an analysis of Matthew as a literary argument also. Due to a different perspective, a narrative analysis is, however, not sufficient when we specifically want to understand the argumentative aspect.

Kingsbury $(1988,3)$ notes that "the element of conflict is central to the plot of Matthew". This conflict arises with different parties in the story: "Satan (4:1-11), demons (12:28), the forces of nature and of illness, civil authorities (such as Herod and Pilate), Gentiles (including Roman soldiers), Israel, and, above all, Israel's religious leaders." It is the conflict between Jesus and the religious leaders that leads to Jesus' death (cf. 1988, 5). After the resurrection, the risen Jesus will also enter into conflict with the nations $(24: 14 ; 25: 31-46)$ through the mission of the Church. Although Kingsbury does not explicitly mention argumentation, his observations indicate that we can reconstruct an argumentative situation on many levels: where there is disagreement, argumentation usually follows.

Kingsbury's analysis clearly shows the literary nature of Matthew. Matthew is omnipresent in relation to the world of his story-there is no scene from which he is absent. He is present with Jesus in the desert, alone, tempted by Satan (4:1); he is with John in prison (11:2), with the disciples in the boat $(14: 22,24)$, etc. Matthew is also omniscient. He knows the words of Jesus' private prayer in Gethsemane $(26: 39,42)$, he knows the feelings of many characters, for instance that Herod is frightened (2:3), and he is also able to describe what characters see or hear (Kingsbury 1988, 32). At a few points the author breaks the frames of the story-world in order to address the reader directly (e.g. in 24:15: "Let the reader understand", and in 27:8 and 28:15). Kingsbury's $(1988,33)$ comment at this point illuminates the role of Matthew:

\footnotetext{
4 There are, of course, comments regarding arguments in almost all exegetical studies, but these do not put the Gospels in a specifically argumentation analytical framework. For a discussion and a bibliography on argumentation analysis in New testament exegesis, especially regarding the letters of Paul, I refer to my dissertation (Hietanen 2007a).
} 
"Matthew as implied author looks back upon the whole of the story of the life and ministry of Jesus of Nazareth and also involves himself, through his voice as narrator, in every aspect of this story."

Kingsbury's remark regarding the narrator is similar to a remark by Dickson (2005, 220) who notes that "even the narrator himself" is a herald of the Gospel. Neither Dickson, Kingsbury, or Howell, however, take much note of how the evangelist takes part in presenting the story-or "involves himself" - not only through the role as narrator, but also through the layout of the story, and through the characters in the story.

Regarding the discussion of the author's intention, I connect with Howell's (1990, 50-51) middle-way between ruling out the author altogether (typical of the so-called New Criticism; Searle 2005), on the one hand, and confining the interpretation to the historical context of the evangelist and his community (as is traditionally done within the historical-critical paradigm), on the other. In agreement with Howell, I do not find it fruitful to approach the text from a perspective where the intent of the author is of no relevance and where a literary work has potentially unlimited readings, all of which are part of the text in the sense that the end-product emerges only in the process of an individual reading - as would be typical for a New Criticism reading. I do, of course, not suggest that we need to confine our reading to any Christian dogmatic boundaries either. Rather, we should try to establish an interpretative space within which we find "educated interpretations". The boundaries of this space are made up of what we know of the historical situation, the meaning of the texts, the conventions of the genre, and so on. The restrictions presented by such knowledge still leave room for different interpretations. At the same time they exclude a host of interpretations that, while they may be subjectively valuable, are less so inter-subjectively since they are difficult to share due to the lack of common interpretative criteria and, in addition, may not at all connect with the original context or the attributable intentions of the author.

Although narrative critics such as Kingsbury and Howell identify the purpose of the Gospel, it is not treated as an argument. Therefore this aspect of the text is more or less lost in their analyses. Matthew does not only wish the reader to receive and to experience the information contained in the text, but also to accept the argument that is put forth.

For instance, Howell $(1990,250)$ notes that the "implied reader has the benefit of the narrator's commentary throughout the Gospel [...] and is told Jesus' identity from the beginning. In this way the implied reader knows more than every character in the story". But it should be noted that the reader does not necessarily accept the narrator's comment! For many a reader, the narrator's comments are standpoints of the author; ones that inform the reading of the story, but that are not necessarily acceptable. An argumentation analytical reading helps us focus on this aspect of the story.

\subsection{Matthew's Argument and Rhetorical Criticism}

In his influential book New Testament Interpretation Through Rhetorical Criticism, George A. Kennedy (1984) presents an overview of the rhetoric of the New testament. Kennedy $(1984,12)$ describes the goal of rhetorical analysis as the "discovery of the author's intent and of how that is transmitted through a text to an audience." The audience is for Kennedy $(1984,5)$ an early Christian, "an inhabitant 
of the Greek-speaking world in which rhetoric was the core subject of formal education and in which even those without formal education necessarily developed cultural preconceptions about appropriate discourse."

Kennedy (1984, 98-100) identifies four "great rhetorical problems of biblical Christianity which have continued to be major objections to the Christian faith", which the evangelists address: (1) the Jews did not accept Jesus as the Messiah, a problem especially dealt with by Matthew; (2) the end of the age had not occurred within one generation after Jesus' death although he had prophesied that it would be imminent; (3) the lack of historical verification of the Gospel account; and (4) whether Jesus was the Son of God in distinction from the many other teachers, healers, and prophets of the time. In addressing these concerns, the evangelists made use of a range of rhetorical techniques by a "careful use of ethos, pathos, and logos, in that order of priority" (Kennedy 1984, 101).

Kennedy $(1984,101)$ notes that Matthew "makes the widest use of all aspects of rhetoric". This is apparent in the careful arrangement of the different parts of the Gospel, and also in the arrangement of proofs. Matthew has a concern "consistently to provide his readers with something close to logical argument. He appears to furnish reason to make what is said seem probable and to allow his audience to feel some intellectual security in his account." (Kennedy 1984, 102). Kennedy mainly focuses on the Sermon on the Mount (Matt. 5-7), but also provides a summary of how he understands Matthew's use of external proofs to show that Jesus is the Messiah $(1984,103)$ :

We are shown that Jesus must be the Messiah because (1) his birth fulfilled the prophecy of the birth of the Messiah, (2) he was so acclaimed by John the Baptist, (3) he was so recognized by God, (4) he was tested and proved true by the devil, (5) the disciples immediately responded to his call, and (6) he could heal the sick.

Kennedy classifies these as external proofs since he compares them to documentary evidence, witnesses, and signs - major forms of external, or inartistic, proofs. In addition to external proofs, Kennedy (1984, 103) notes that Matthew also "employs the internal proof of logical argument" through characters in the story, who regularly "speak in enthymemes" by supporting an assertion with a reason. Kennedy $(1984,104)$ concludes that, "[f]or all its miraculous events, Matthew's world is far more rational than that described by Mark."

Ground-breaking as they are, Kennedy's findings need to be refined. First, most of the proofs that Kennedy classifies as external proofs should more precisely actually be understood as internal proofs, as inventions by the author (or the tradition that he uses). It is untenable for us to regard supernatural events and miracles as external proofs. Take, for instance, Kennedy's fourth proof (in the quotation above). Even according to the evangelist himself, no one else was present when Jesus was tested by the devil. This can hardly, then, be compared with laws, witnesses, contracts, torture, or oaths (the five external proofs according to Aristotle 1994, I.15.2), which presuppose physical evidence or the presence of other humans. In any case, we need at least to allow for the possibility that the whole story is a fabrication by the evangelist (or by the tradition that he uses). Second, it is unclear how Kennedy arrives at this set of six proofs. A more systematic analysis is needed. 
Rhetorical criticism and argumentation analysis are closely related. The former is by now a well-established method within New testament exegesis. The latter has also been explored, but to a much lesser extent (I refer, again, to Hietanen 2007a).

\subsection{Matthew's Argument and Argumentation Analysis}

\subsubsection{An Analytic Overview}

Van Eemeren et al. (1996, 288) suggest that an analytic overview of an argumentative discussion should include the following five points: $(a)$ the standpoints at issue in the difference of opinion; $(b)$ the positions adopted by the parties, their starting points and conclusions; $(c)$ the arguments adduced by the parties; $(d)$ the argumentation structure; and $(e)$ the argument schemes used in the arguments. Here a reduced overview will suffice. ${ }^{5}$

The first step, then, is to identify the main standpoint and the supporting arguments. A standpoint is an "externalized position of a speaker or writer in respect to a formulated opinion" (Eemeren and Grootendorst 1984, 5). Furthermore, a standpoint implies specific commitments, such as a commitment to defend it, if asked to do so, by providing arguments. The defence can be directed towards someone who holds a different standpoint, someone who simply disagrees with the standpoint, or even someone who just doubts the standpoint.

Argumentation arises when there is a difference of opinion, either implicitly or explicitly. Consequently, we need to identify a position of another party. It is enough that another party expresses doubt regarding an utterance, but such doubt often remains implicit, making it more difficult to identify with certainty (Eemeren et al. 2002, 12). In an implicit discussion, utterances that are strongly contrary to the status quo are usually meant as standpoints since they probably will raise either doubt, rejection, or other, competing, standpoints. Although crucial for the analysis, the process of identifying standpoints and differences of opinion is not necessarily easy since a discussion may contain any number of arguments, and much in the discourse may be implicit or expressed unclearly.

Regarding Matthew it could be argued that Matthew is a story, a narrative, and not an argument. However, many narratives contain arguments. Even if the author of a story did not intend to make an argument, an argument may arise if the reader does not accept some of the propositions within the story. We do not know about the author's intentions in this respect, but the message he puts forth is in such contradiction with what many people-original or contemporary-would hold true or believe, that it for many becomes an argument. It is therefore warranted to apply the strategy of a maximally argumentative interpretation, i.e. to consider statements as argumentation when one is uncertain as to whether or not they are meant as argumentation (Eemeren et al. 2002, 42).

\footnotetext{
5 Argumentation can be defined as follows (Eemeren and Grootendorst 1984, 18): "Argumentation is a speech act consisting of a constellation of statements designed to justify or refute an expressed opinion and calculated in a regimented discussion to convince a rational judge of a particular standpoint in respect of the acceptability or unacceptability of that expressed opinion."
} 
What is, then, the main bone of contention in Matthew? Viewed from the perspective of the implied reader, the centre of the Gospel is the person of Jesus: who he was and what he did. If Jesus was not the Messiah, the long-awaited son of David, then all the prophecies related to him presented in Matthew would be irrelevant. If Jesus was not the Son of God, but just an ordinary man, his promises about the future, his teaching about heavenly matters, and his demands would loose both credibility and relevance. Based on my reading of Matthew, I conjecture to formulate the main standpoint as follows: "Jesus is the Son of God, the Messiah." If this standpoint is correct, the main arguments put forth in the Gospel should support it. My identification of the main standpoint is in agreement with that of Kennedy (as presented above), and also comes close to Kingsbury's and Howell's identifications of the message of the Gospel, as it emerges from a narrative analysis (neither, however, set out to formulate a standpoint for Matthew). Howell (1990, 159) describes the element of confrontation in the story and how this transfers on to the reader:

Matthew opens his Gospel by introducing his protagonist Jesus, the Son of God, whose mission is to save his people from their sins. His coming provokes a crisis as characters in the story are confronted with the choice of accepting or rejecting him and his proclamation of the Kingdom of God. Acceptance or obedience to Jesus' teaching is the proper response according to the evangelist, and the implied reader is challenged to respond correspondingly in the open-ended conclusion to the Gospel.

I agree with Howell that the story aims at a response from the reader. In this sense we have two standpoints, one explicit and one implicit. The explicit standpoint is that Jesus is the Son of God, the Messiah, and it is most clearly presented through the apostle Peter, in Matt. 16:16, where he gives this dramatic and fundamental confession to Jesus: "You are the Messiah, the Son of the living God." The implicit standpoint relates to the consequence of the explicit one. If the reader accepts the proposed identity of Jesus, he should also arrange his life accordingly and change role from one being evangelized to one carrying out the Great Commission to make all nations into disciples (Matt. 28:18-20). The latter aspect can be construed as the main implicit standpoint. In this analysis I will focus on the explicit standpoint, which is the basis for the implicit one.

I focus on audiences on two levels: the audiences within the story and the audiences in the real world. Both of these function as antagonists to the main standpoint. The first group consists of disciples, crowds of people, Pharisees, different authorities, etc. From a narrative point of view, some of these audiences are at the same time the projected audiences of Matthew: a reader of the Gospel may react in the same way as a character in one of the stories. As mentioned above (p. 2), I will here understand Matthew's audience in a wide sense and not focus on his immediate community, which already accepted Jesus as the Messiah. ${ }^{6}$

\footnotetext{
${ }^{6}$ For those who have already accepted the main standpoint, the Gospel functions in a non-argumentative way, as a reminder of the foundation for their faith, as a source for insight, instruction, comfort, and exhortation. As mentioned above, however, also believers need arguments for their faith.
} 
When formulating an argumentation structure for Matthew it is clear that we are not reproducing the author's blueprint for the text. Rather, we are creating a heuristic tool for understanding one aspect of how the different parts of the text function with regard to one of the purposes of the whole text, namely to support the standpoint that Jesus is the Son of God, the Messiah. It is interesting that when we take this as the main standpoint, it is not at all difficult to subordinate the rest of the Gospel as arguments in support—an indication that this analysis does indeed capture a feature inherent in the text.

The main question is what arguments are put forth in support of the standpoint. After careful readings of the Gospel I find that the material can be placed in six categories - or lines of argumentation-, each supporting the main standpoint in a different way: (a) Jesus' birth and infancy; $(b)$ the reactions Jesus received from others; $(c)$ the indications of several prophecies; $(d)$ the features of Jesus' ministry; (e) Jesus' teaching; and $(f)$ Jesus' death and resurrection. Note here that my analysis has resulted in a different set of arguments than those of Kennedy (presented on p. 5, Sect. 2.3). Let me elaborate on the argumentation structure and then present my analysis in a table.

How do these arguments support the standpoint: multiply or coordinatively? At first glance, it could seem that Jesus' death and resurrection would be enough to support the main standpoint, and similarly the circumstances of his birth. Some would argue that his teaching or his ministry would give enough support or that we should be convinced by the reactions of the people Jesus is recorded to have met. However, because of the following reasons, I find the structure to be coordinative.

Although remarkable, a divine birth (a) is not enough to prove that Jesus was the Messiah; antiquity tells of many divine births. Jesus' death and resurrection (f), is also not enough since many people were crucified, and although resurrection is certainly extraordinary, it is not unique in this context-Matthew himself tells of other resurrections (performed by Jesus and occurring at his death also). Jesus' teaching, (e), although extraordinary, was not unique in the sense that there would not have been other remarkable prophets and teachers. There were many of them and some even got similar reactions from the crowds, for instance John the Baptist, so (b) is also not enough by itself. The same goes for Jesus' ministry, (d). As for (c), not only are the prophecies applied hundreds of years after they were given, but selected somewhat ad hoc, based on some similarity with what they are supposed to prove and are therefore weak as arguments.

Consequently, none of these is by itself enough to support the standpoint that Jesus was the Son of God, the Messiah. The impression of the text is that arguments, stories, examples, and formula-quotations ${ }^{7}$ are stacked on each other so that, if not at the beginning, at least at the end, the reader or hearer of the Gospel would accept the standpoint of the author.

I have earlier presented a possible argumentation structure for the Gospel of Matthew (Hietanen 2007b, 610-611). In Table 1 I reproduce the main part of this

\footnotetext{
7 The so called formula-quotations, which are typical of Matthew, give an Old testament text as an argument for Jesus, or for some particular of his life and ministry, as a fulfilment of an Old testament prophecy, often introduced by a phrase like "This was to fulfil what had been spoken by the Lord through the prophet." (Matt. 2:15).
} 
Table 1 The Structure of the argument of Matthew

1 JESUS IS THE SON OF GOD, THE MESSIAH (1:1)

\section{1a Jesus' birth and early childhood indicate this}

Jesus' genealogy shows that he was the son of David. (1:1-17); Jesus was conceived by the Holy Spirit, born of virgin Mary. (1:18-25); The wise men's visit from the East was testimony that Jesus was king of the Jews. (2:1-11); Several circumstances of Jesus' birth and infancy conform to prophecies. $(2: 13-3: 1)$

\section{$1.1 \mathrm{~b}$ The reaction of others indicates this}

Herod was afraid that Jesus might be the Messiah. (2:3-16); John recognized Jesus' identity. (3:13-15); At the baptism by John, God supernaturally confirmed Jesus as the Son of God. (3:16-17); Simon Peter, Andrew, and James and John (Zebedee), and Matthew recognized Jesus' authority. (4:18-22)

\section{1c Several prophecies indicate this}

(Some prophecies were already mentioned under 1.1a) Jesus settled down in Caphernaum. (4:12-16); Jesus healed many. (8:16-17); Jesus was not boastful. (12:15-21); Jesus taught in parables. (13:34-35); Jesus rode in to Jerusalem on a donkey. (21:2-5); Judas' thirty pieces of silver were used to buy the potter's field. (27:6-10)

\section{1d Jesus' ministry indicates this}

Jesus healed a large amount of people in many places who were sick by birth, illness or demons. (4:23-24; 8:2-3; 8:6-16; 8:28-33; 9:20-22 et al.); Jesus raised a few dead. (9:18-26; 11:5); Jesus had command over the elements. (8:23-27); Jesus forgave sins. (9:1-8); Jesus addressed God as "my Father"; Jesus performed miracles (e.g. 15:32-38)

1.1e Jesus' teaching indicates this

Jesus' teaching was extraordinary. (4:23-25; 5:1-7:28 et al.)

1.1f Jesus' death and resurrection indicate this

There were supernatural events at Jesus' death (27:51-53); Jesus rose from the dead (27:63-28:17)

structure, including the arguments on the first level under the main standpoint. I also include a few arguments on further sub-levels, unnumbered, to indicate how different parts of the text can be viewed as supporting arguments. The six arguments or sub-standpoints could be put in brackets to indicate that they are not explicit in the text, but here I only wish to present my reconstruction of what I find to be the six main lines of argument in support of the main standpoint; I do not attempt a technically complete structure.

\subsubsection{An Example: The Virgin Conception}

I take one argument as an example, a well-known one that is presented right at the beginning of the Gospel, after the genealogy (cf. argument 1.1a): the virgin conception (Matt. 1:18-23). The following argument is put before Joseph by an "angel of the Lord" in 1:20: "Joseph, son of David, do not be afraid to take Mary as your wife, for the child conceived in her is from the Holy Spirit." This is a single argument with one unexpressed premiss: If the child in Mary is conceived by the Holy Spirit, then you (Joseph) should not be afraid to take her as your wife.

\footnotetext{
8 The argumentation structure can conveniently be displayed by using the schematic presentation for complex argumentation structures suggested by van Eemeren and Grootendorst (1992, 73-89).
} 
Kennedy $(1984,103)$ notes that the angel presents the first enthymeme in Matthew and that "[t]his is a logical angel who wants Joseph to understand and is not content simply to make authoritative announcements."

When Mary became pregnant, Joseph supposed that she had been with another man. No self-respecting Jew would have married Mary under such circumstances (cf. Deut. 22:13-24). In the story, the angelic visit explains why Joseph did not abandon her but took her as his wife and adopted Jesus: he was convinced by an angel. Let us take a look at how Matthew convinces the reader. The whole passage reads (New Revised Standard Version Bible 1995):

Now the birth of Jesus the Messiah took place in this way. When his mother Mary had been engaged to Joseph, but before they lived together, ${ }^{9}$ she was found to be with child from the Holy Spirit. Her husband Joseph, being a righteous man and unwilling to expose her to public disgrace, planned to dismiss her quietly. But just when he had resolved to do this, an angel of the Lord appeared to him in a dream and said, "Joseph, son of David, do not be afraid to take Mary as your wife, for the child conceived in her is from the Holy Spirit. She will bear a son, and you are to name him Jesus, for he will save his people from their sins." All this took place to fulfil what had been spoken by the Lord through the prophet: "Look, the virgin shall conceive and bear a son, and they shall name him Emmanuel", which means, "God is with us."

The evangelist presents a text with the purpose of explaining how the birth of "Jesus the Messiah took place". Joseph's action, the angel's announcement, and Isaiah's prophecy are all presented as arguments in favour of the standpoint that Jesus was born by a virgin, conceived by the Holy Spirit. The argument is symptomatic, ${ }^{10} 1.1,1.2$, and 1.3 are all signs: since they witness to the virgin conception, we should accept it, see Table 2.

Argument 1 That Joseph did not abandon Mary, but adopted Jesus as his son, is a sign that he accepted that the child was not conceived by another man, but by the Holy Spirit. Since a righteous Jew normally would have divorced a betrothed with an illegitimate child, the argument is strong. Something out of the ordinary would have been needed in order for Joseph to stay with Mary, such as an angelic visit testifying to the divine origin of the child.

Argument 2 For an angel to appear, the reason must have been important. The angel testifies both to Joseph and to the reader: that Joseph believed the angel incurs also the reader to believe him.

\footnotetext{
9 The Greek word synerchomai literally means "come together" (NRsv: "they lived together"). Without euphemizing we would say "before they had sexual intercourse, she was found to be pregnant from the Holy Spirit" cf. Louw and Nida (1999).

${ }^{10}$ In Pragma-Dialectic theory, argument schemes are divided into three categories, analogous, causal, and symptomatic. In a symptomatic argument "a standpoint is defended by citing in the argument a certain sign, symptom, or distinguishing mark of what is claimed in the standpoint" (Eemeren et al. 2002, 96-97).
} 
Table 2 Matt. 1:18-23: The virgin conception

1 JESUS WAS CONCEIVED BY THE HOLY SPIRIT, BORN BY VIRGIN MARY

1.1 Joseph believed this

Joseph did not dismiss Mary when he found she was pregnant.

1.2 An angel announced this

An angel said, "Look, the virgin shall conceive and bear a son, and they shall name him Emmanuel", which means, "God is with us."

\subsection{This was foretold by the prophet Isaiah}

Isaiah prophesied, "the young woman is with child and shall bear a son, and shall name him Emmanuel."

Argument 3 Also here the argument scheme is symptomatic: the prophet Isaiah is used to back up the standpoint. ${ }^{11}$

As is clear from Table 2, I understand the argument to be multiple. For Matthew, Joseph's action, the angel's testimony, and Isaiah's prophecy are three different lines of argumentation in support of the standpoint. Joseph's action is the only strong argument since it is so concrete. The reference to Isaiah is the weakest of the three since it is so remote, and the angelic visit is both abstract and a rather (redactionally) convenient explanation for Joseph's action.

The structure presented in Table 1 as well as the brief example-analysis of 1:18-23, illustrate that Matthew can indeed be viewed as an argument in support of the standpoint that Jesus is the Son of God, the Messiah. Although the form of the Gospel is that of a narrative, it contains indirect argumentation.

However, analysing religious arguments such as the one about the virgin conception requires the analyst to take several aspects into account. First, the literary nature of the story makes the analysis more complex. For instance, the story functions on three levels: between the characters in the story (the dialogue between Joseph and the angel), between the evangelist and the intended reader (Matthew's explanation that "all this took place to fulfil ..."), and through the characters to the reader (that Joseph believes the angel leads the reader to do so also). More on this in Sect. 3. Second, contextual information is needed, especially about the make-up of a Jewish-Christian world-view, in which, for instance, a prophecy and an angel can appear as premisses in an argument. Third, we note that the reader is required to invest a lot of trust in the reliability of the evangelist since no concrete evidence is available.

\footnotetext{
${ }^{11}$ The references are to Isaiah 7:14 and 8:8, 10. However, if we exclude the possibility of supernatural foreknowledge, Isaiah did not have parthenogenesis in mind, nor the birth of a Messiah several centuries later (cf. Luz 1985, 105). Regardless of the original meaning of the passages in Isaiah, the evangelist interprets the text in such a way that it can be used as an argument for the virgin conception: it was foretold.
} 


\section{Literary Argument Design in Matthew: The Gadarene Demoniacs}

\subsection{A Pragmatic Literary Analysis}

If we want to understand the effect a certain way of telling a story has (wording, style, content, etc.), sophisticated tools are useful. Through a pragmatic analysis it is possible to present explanations for how the story functions, and also for why Matthew has made certain changes in comparison with Mark.

After the following description of how Gricean insights can be put to use in analysis of literature, I present a pragmatic analysis of the story of the Gadarene demoniacs (Sects. 3.2, 3.3). After the analysis I reflect on the significance of the literary and historical nature of the story for the analysis (in Sect. 3.4).

Building upon the theories of Searle (1975) and Grice (1975), Pratt (1977) develops a theory for a pragmatic literary analysis. She focuses on conversational implicatures, ${ }^{12}$ which she argues are equally important in literary texts as they are in natural narratives (Pratt 1977, xii). She $(1977,158)$ notes that "[w]ithout implicature, it would take us a long time indeed to say anything at all." An overtly explicit discourse is tedious to read or listen to and stylistically poor. Since the reader assumes that the Cooperative Principle and the Gricean maxims are being observed on a given occasion, ${ }^{13}$ the author does not need to spell out all the intermediate stages in a story. On the other hand he or she can exploit the possibility of more than one explanation or implicature (Pratt 1977, 154-158).

A pragmatic literary analysis enables the analyst to explain and justify intuitive reactions of a reader by describing what kinds of interpretation the text invites the reader to. This is an extension to Grice's theory since literary texts exhibit features that are different from natural discourse. For instance, the exploitation of the maxims, which is a common feature of literature, runs contrary to Grice's fundamental expectation of a "maximally effective exchange of information" in natural discourse (Grice 1975, 47). This is due to the fact that the purpose of a literary text is (usually) not to convey information, but to entertain, to influence, to evoke a response in the reader. ${ }^{14}$ Pratt calls this quality of literature "tellability". An author produces a "display text" that contains "displaying assertions". Allowing for displaying assertions, Grice's $(1975,45)$ Cooperative Principle can be seen to hold

\footnotetext{
12 Implicature is Paul Grice's term to denote the type of non-literal meaning that is conveyed when a conversational maxim is (supposedly) deliberately flouted in order to comply with another maxim that is (supposedly) considered more important in the situation while the Cooperative Principle is maintained (Grice 1989).

13 Grice (1989) formulates the Cooperative Principle thus: "Make your contribution such as it is required, at the stage at which it occurs, by the accepted purpose or direction of the talk exchange in which you are engaged." The maxims are those of Quality (Only say what you believe to be true and what you have evidence for), Quantity (Make your contribution as informative as is required for the current purposes of the exchange), Relevance (Make your contribution relevant to the interaction), and Manner (Be clear).

14 The Gospels are a mixture of genres and can thus have several functions simultaneously. Although one of these functions is to convey information, the other functions give ample room for the exploitation of maxims in a way typical for literary texts.
} 
also for assertions where the purpose is some other than information (Pratt 1977, 153). Pratt (1977, 136) notes:

In making an assertion whose relevance is tellability, a speaker is not only reporting but also verbally displaying a state of affairs, inviting his addressee(s) to join him in contemplating it, evaluating it, and responding to it. His point is to produce in his hearers not only belief but also an imaginative and affective involvement in the state of affairs he is representing and an evaluative stance toward it. He intends them to share his wonder, amusement, terror, or admiration of the event.

Even though all forms of failure to fulfil a maxim can be exhibited in literature, it all boils down to flouting on the part of the author who can exploit the maxims in his text (Pratt 1977, 148-175). The reader knows that he or she is reading a literary work and precisely because of this can he or she discover the implicit meanings intended by the author (Pratt 1977, 116). Pratt (1977, 174) summarizes this as follows:

Authors, in other words, can mimetically represent all kinds of nonfulfillment, for what counts as a lie, a clash, an opting out, or an unintentional failure on the part of the fictional speaker (or writer) counts as a flouting on the part of the real-world author and involves an implicature that the nonfulfillment is in accord with the purpose of the exchange in which the reader and author are engaged.

Pratt differentiates between two levels of implicature: what the author implies and what the characters in dialogues in the story imply. Leech and Short (1981, 303), who build upon Pratt, expand Pratt's first level into two separate levels of implicature: what the author conveys by an implicature through his commentary and what he or she conveys by an implicature through the utterances of the characters in the story. This is a useful extension.

Our tolerance for deviations from the maxims is different for display texts and for ordinary discourse (Pratt 1977, 147). Consequently, Grice's maxims would need to be adjusted to include the tellable. Neither Pratt, nor Leech and Short, elaborate on this, but they show that Grice's theory can be used as long as the analyst interprets the maxims in a way suitable for the literary genre in question.

Some utterances have very clear implicatures, while others can be reconstructed in different ways. The analyst therefore needs to be careful not to be more determinate in his analysis than the utterance allows for. If we have various possible explanations for what is implied, then the "implicatum will have just the kind of indeterminacy that many actual implicata do in fact seem to possess" (Grice 1975, 58).

Next, I will apply a literary pragmatic analysis on a well-known passage in Matthew. First (Sect. 3.2), I place this particular passage in its context and give a brief general analysis. Then (in Sect. 3.3) I move on to a detailed analysis of the implicatures in the text. 


\subsection{The Exorcism of the Gadarene Demoniacs}

Exegetical commentators regularly notice that the purpose of the story of the Gadarene demoniacs in Matt. 8:28-9:1 is "to show the authority of Jesus even over supernatural powers" (France 1990, 165), but usually little explanation is given for how the author goes about doing this. Since Matthew has used Mark as a source, a comparison between Matthew's version and Mark's gives insight into Matthew's style and emphases. ${ }^{15}$ Commentators note that the changes in Matthew are "in the service of a positive intention for the narrative" (Luz 1989, 45). But even where such comments are present it is unusual for them to be based on an analysis of exactly how Matthew's literary and redactional contributions function "in the service" of this or that intention or how we can arrive at an understanding of what precisely this intention is. As I noted above, the purpose of the miracle-stories can be seen as supporting the argument that Jesus' ministry indicates that he was the Son of God, the Messiah (cf. argument 1.1d in Table 1, p. 9).

The story about the Gadarene demoniacs in Matt. 8:28-9:1 occurs in a section containing a selection of ten miracle stories (8:1-9:34). The purpose of these stories is generally described as showing the authority of Jesus the Messiah. In Matt. 5-7 Jesus impresses with his teaching (cf. 1.1e, p. 9) and in Matt. 8-9 with his deeds (cf. 1.1d; cf. France 1990, 150-151). How exactly does the evangelist use a story such as the one about the Gadarene demoniacs to achieve this purpose? What implicatures can we infer from the story to this end? I first deal with general features of the text and then move on to a more detailed analysis (in the next Sect. 3.3). The text reads as follows (with my paragraph breaks; for Mark's version, see Table 3 on p. 15).

$8: 28$ When he came to the other side, to the country of the Gadarenes, two ${ }^{16}$ demoniacs coming out of the tombs met him. They were so fierce that no one could pass that way. 29 Suddenly they shouted, "What have you to do with us, Son of God? Have you come here to torment us before the time?"

30 Now a large herd of swine was feeding at some distance from them. 31 The demons begged him, "If you cast us out, send us into the herd of swine." 32 And he said to them, "Go!"

So they came out and entered the swine; and suddenly, the whole herd rushed down the steep bank into the lake and perished in the water. 33 The swineherds ran off, and on going into the town, they told the whole story about what had happened to the demoniacs.

\footnotetext{
15 Although Matthew shows many changes with respect to his sources, these changes are mostly minor: he subordinates himself to the tradition, respecting the authority of the versions before him, Mark and Q (Luz 1985, 32).

16 Why Matthew changes the one demoniac in Mark to two is difficult to explain. Such a doubling of characters is also found in 9:27-31 and 20:29-34. This was, however, "completely within the scope of a narrator's freedom" (Luz 1985, 24). I here have to forgo commenting on other such changes that are not pertinent for my analysis.
} 
Table 3 The text of Mark 5:1-21

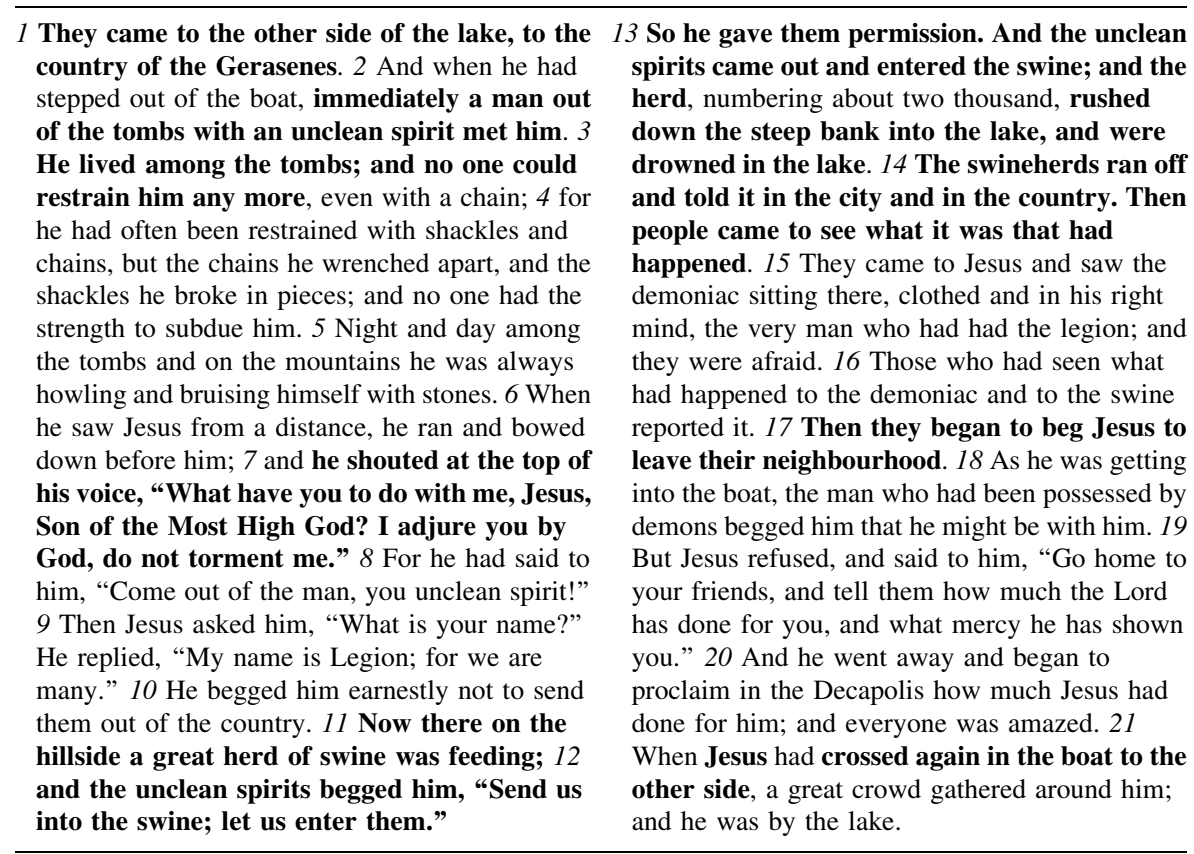

The parallel text in Mark is longer and more detailed than Matthew's version. Parts included in Matthew are set in boldface. The indications are only approximate since several passages are rewritten in Matthew

34 Then the whole town came out to meet Jesus; and when they saw him, they begged him to leave their neighbourhood. 9:1 And after getting into a boat he crossed the water and came to his own town.

This story is a good example of how the author steers the reader without stating very much directly himself as narrator. Instead, the characters and events in the story speak on behalf of the evangelist. It is not the narrator Matthew who calls Jesus "Son of God", but the demoniacs of the story. In the story it is the swineherds who testify to the event and who run off and tell the story. As the arguer for his standpoint, Matthew is only implicitly present. The reader is left with a seemingly direct testimony of Jesus as the Son of God-the Messiah, with supernatural powers, such as the power to exorcize demons in a spectacular way. Argument by example and testimony is often more effective than plain assertion. A vivid story engages the reader by making the situation concrete. This is much more effective than just to state that Jesus has power over demons.

The dialogue gives a certain impression of Jesus. In the whole passage, Jesus only says one single word, the command "Go!" (v. 32), which occurs precisely in the middle of the story. Jesus does not take his turn after the first utterances of the demoniacs. After their second turn, he only utters one word, a strong command with a spectacular effect. This contributes to a picture of Jesus as a figure of authority: he does not engage in conversations with demons, and when he does address them, it is to their peril. 
Even before v. 32, the reader constructs an image of the situation, according to which Jesus is about to exorcize the demons from the demoniacs. The questions in v. 29 create an expectation that Jesus has indeed come "to do" something with the demoniacs, to "torment" them. Although this event is conditional ("if you cast us out"), the reader expects it-especially in view of Matt. 8:16 a little earlier in the Gospel-story, which in a summary fashion reports that Jesus cast out spirits of "many who were possessed". Now the reader gets the first account of one such occasion.

When the "whole town" begs Jesus to leave, he is not reported to have said anything, just to have boarded a boat. That he leaves without comment carries an effect. He did not engage in conversation with the demons, nor does he do so with the critical town folk.

There is a contrast between the obvious miracle just witnessed by the swineherds and their incomprehension of what the miracle says about Jesus. The reader has already at the beginning of the Gospel had Jesus introduced as "Son of God", the Messiah, but the characters in the story meet Jesus for the first time. Clearly this one miracle of exorcism was not enough for the people in this area to understand that Jesus brought good news. But for the reader, Jesus' authority is reinforced by the story and thereby also Matthew's main argument in the Gospel.

\subsection{Argument Design with Implicatures: Matt. 8:28-9:1}

How exactly does Matthew's story present this compelling argument in favour of Jesus' identity? How is the story designed so as to function as an argument? Let us take a closer look at some of the details from the point of view of a pragmatic analysis.

After the orientation (the place and the persons and their situation) in v. 28, Matthew introduces the first utterance with "suddenly they shouted". Through the addition of "suddenly", Matthew gives the dialogue a sense of immediacy, an indication of Matthew's use of literary devices. It also indicates that the demoniacs had been quiet during the time immediately preceding Jesus' approach. Thus, already before the dialogue begins, the reader is sensitized to expect that the demoniacs are reacting to the person of Jesus in a special way. That even Jesus' enemies, the demons, identify him as the Son of God is an argument for the reader to accept this identification. It is an example of an indirect argument through the characters of the story.

The first utterance (v. 29) raises for the reader an expectation of action: the demons anticipate that "the Son of God" will do something to them during this encounter. Although the demons' questions require an answer, Jesus gives none. Instead Matthew inserts a description of how a herd of swine were feeding nearby. This flouting of the maxim of Relevance is stylistically quite powerful. The swine have no relevance to the questions of the demoniacs (v. 29): they do not appear to be an answer, and they do not thematically relate to anything so far in the story. However, the reader intuitively supposes that the author adheres to the Cooperative Principle and thus tries to figure out how the swine could be relevant. This expectation is suspended until the next turn of the demons in the dialogue. To 
summarize: Matthew creates a dramatic effect by (1) not providing an answer to the first turn of the demoniacs in what would be expected to be a dialogue, and by (2) instead providing a seemingly irrelevant piece of information about a herd of swine. The reader thus at this point has a dual expectation: what is Jesus' answer? and what is the role of the herd of swine?

The next utterance (v. 31) by the demons is presented with "the demons begged him". This shows that their initial fear that Jesus would "torment" them is still in effect. In addition, they acknowledge their inferior position in relation to him: they are in a position to beg. This is in stark contrast with the initial description of the context and situation from which we are told that the demoniacs were "so fierce that no one could pass that way" - no one except Jesus, that is: an implication that at this point becomes clear. Also, a preparatory condition for a request is that the speaker believes that the hearer is able to fulfil the request. In other words, even Jesus' enemies, in this case the demons, acknowledge Jesus' power to exorcize.

The second utterance makes clear that the action feared by the demons-and at this point anticipated by the reader-is one of exorcism. The request is an odd one ("... send us into the herd of swine"). Why not rather make a request that Jesus would leave them alone? or to make some threat-a normal reaction when threatened. The implication is that the demons have no alternative. Matthew indirectly conveys to the reader that the demons know that there is no alternative to the exorcism: they will be cast out. On this point Matthew's account differs from Mark's where the exorcism turns out to be more difficult. Here the purpose of emphasizing Jesus' authority does not give room for the speech exchange between Jesus and the demons that we have in Mark (5:6-10).

Why do the demons request a transfer to the swine? From a later passage in Matthew we know that an exorcism normally means that the demons become "homeless". ${ }^{17}$ This is clearly an unwanted state so the focus of the request is on having a host, not on the identity of the new host. The presence of a herd of swine is mere serendipity. However, a transfer into the swine is not much better than immediate destruction - it only postpones their end (This holds true even without the subsequent event of the swine drowning-later they would have been slaughtered for food). Consequently, the request to be transferred into the swine is nothing short of a desperate attempt for the demons to find a way out of an impossible situation.

The "if" in the utterance is weak (it would at this point be very surprising if no exorcism would take place in the story), but it upholds the suspense for the reader. At this point the expectation for Jesus' answer has been building up-which is especially clear from the point of view of the theory of turn-taking (Jefferson et al. 1974). How will Jesus respond to the two previous questions and the one request? With a minimum of neutral introduction ("and he said to them") Jesus' answer is given. Skipping over all other expectations, Jesus' utterance jumps to a fulfilment of the request. By uttering "Go!" he sends the demons into the swine, as is explained in the narration (v. 32). By answering a request by a command Jesus is portrayed as

\footnotetext{
17 Matt. 12:43: "When the unclean spirit has gone out of a person, it wanders through waterless regions looking for a resting place, but it finds none."
} 
a figure of authority. Of course, "Go!" on its own would not constitute the speech act of exorcism. It is only in the specific context where the command is directed towards demons, with the intention of freeing one or several persons from one or several demons that such a command can be taken as an attempt to exorcism. Matthew knows this and has presented the setting in a way in which the simple utterance "Go!" can function as a command for exorcism.

To add to the drama, Matthew records the reactions of the swineherds, who run off telling about the event to the townsfolk. Although nothing is said about their emotional response, the description of their actions suggests that they were afraid ("ran off"), and so also the others in the town ("they begged him to leave"). It is interesting to note that at the end of the story, even though the whole town is in opposition to Jesus, they still utter a request—not a command-for him to leave. Thus, even in leaving the scene as unwanted, Jesus retains his authority in the story.

Unusual for a dialogue, it consists solely of directives. Both the demons/ demoniacs and Jesus attempt to get the hearer to do something. Even though the success of Jesus' exorcism is a given, it is not a priori clear that one speech act will suffice, as we see in the Markan account where the initial command is insufficient. Jesus' command should thus not be understood as a declarative, where the performance of the speech act brings about "the correspondence between the propositional content and reality" (Searle 1975, 358).

In the above analysis we see how different levels in the story communicate to the reader. It is clear that a mere understanding of the syntactic and lexical structure only gives a part of what is communicated. Matthew uses pragmatic devices to communicate more than what is said technically. Let us take a look at the three levels of implicatures at work in the story (cf. the theory of Leech and Short, Sect. 3.1).

On the level of character-to-character utterances we have the dialogue between Jesus and the demons. Second, we have the level of authorial commentary, and thirdly, a level through the character-to-character level. To make this clear, let me recapitulate an example of an implicature on each of these three levels (see also my analysis of the virgin conception, Sect. 2.4.2, where these three levels are also clearly present).

Implicature on the character-to-character dialogue-level: Jesus' utterance in the dialogue is restricted to one single word. Two questions and one request are answered with one command. By not answering the questions of the demons (a violation of the maxim of Quantity), Jesus implies that he does not engage in conversation with demons: they have no bargaining-position whatsoever. ${ }^{18}$

Implicature on the authorial commentary level: Instead of an answer (to the questions of the first turn of the demons in the dialogue with Jesus), Matthew gives a piece of seemingly irrelevant information, Matt. 8:30. This is a violation of the maxim of Relevance by which he implies that the herd of swine is going to play a

\footnotetext{
18 Should we rather understand Jesus as opting out from the operation of the maxim and of the Cooperative Principle? That Jesus fulfils the request about a new host indicates that Jesus is not opting out.
} 
role in the continuation of the story. This is a clear example of the use of implicature as a literary device.

Implicature through the character-to-character dialogue-level: Matthew has the demons request Jesus to grant them swine as new hosts, which is strange. One would rather have expected resistance towards Jesus. Through this exploitation of the maxim of Relevance, Matthew conveys by an implicature that Jesus' authority is unquestioned for the demons—a difference to Mark's account (Mark 5:7-8). This serves Matthew's purpose of emphasizing Jesus' authority.

It is generally considered that Matthew used Mark 5:1-21a as the source for this story (Luz 1989, 23). By comparison, Matthew's story is considerably shorter and for instance by Luz considered to be "less vivid". However, as the analysis above indicates, Matthew's use of pragmatic devices is intentional. Space does not here permit a point-by-point comparison, but it is clear that Matthew is not foremost interested in presenting the story as it supposedly happened with all its details, but to capture a certain aspect of it. The aspect that Matthew emphasizes is the authority of Jesus and his identity as Son of God with power over demons. This is only one such example of how Matthew uses the material of miracle-stories as arguments for his main claim that Jesus is the Son of God, the Messiah.

\subsection{The Gospel as a Literary Argument}

A pragmatic analysis provides the necessary instruments to describe certain features of a text such as Matt. 8:28-9:1. Not only does it make it possible to describe the dynamics of the dialogue and the narrative and the point of the whole story, but it also gives us an understanding of how the story works from the point of view of the author's attributable intentions.

It is not satisfactory just to state that Matthew's text has "literary qualities" or to list the textual differences between his account and for instance the Markan account of the same story. We need to understand the effect of these changes and this requires a contextual analysis.

The analysis of Jesus' encounter with the Gadarene demoniacs shows that Matthew makes use of implicature to create a dramatic story that enhances the reader's impression of Jesus' authority. A pragmatic literary analysis is well suited to describe how this is done.

Is our text a display-text? Is Matthew reporting a state of affairs or merely verbally displaying an imagined state of affairs? (cf. my discussion of Pratt above). With regard to the thesis that Jesus is the Son of God it would not be a good strategy to invent purely fictitious proofs. On the contrary, it is important for the story to carry as much historical credibility as possible. The reader should believe that what is reported took place in reality.

On the one hand, then, although the Gospel of Matthew has features which we as analysts clearly can identify as literary features, they do not automatically hinder us from reading the story as history. On the other hand, although the purpose of the Gospels and the miracle-stories is not to function as display-texts, it is certainly possible for a modern reader to read them in such a way. An argumentation analysis of the Gospel does not decide the matter: both a historical account and a display-text 
can be analysed as arguments. For the perlocutionary effect of the argument of the Gospel, ${ }^{19}$ however, historicity is important (for many readers, but not for all). A reader who is not convinced that the stories of Matthew are true is less likely to be convinced of any standpoint that they are intended to support.

Consequently, a crucial part of the success of the argument depends on to what extent the reader accepts the specific sets of felicity conditions of Gospel-stories. For instance, one characteristic of the Gospels is that Jesus and his disciples can perform miracles. In a novel by, say, Jane Austen, someone walking on water, for example, would immediately by the reader be interpreted as a violation of the maxim of Quality, but in the realm of the divine such events are acceptable. On the other hand, to the extent that the reader expects a historical account, the divine features of the story clash with empirical knowledge of the world. To further complicate things, readers in different times have different expectations, depending on their worldviews and on their conception of history. This makes the Gospel-story a complicated mix and the reader is confronted with questions relating to a higherorder condition of Matthew's argument, to what is possible in this world.

For the analyst to achieve an interpretation that is true to the story, he or she needs to be able to relate to the characters, the settings, the conflict, etc. from a perspective close to that of Matthew's. Without a proper historical perspective, the story runs the risk of being appropriated in whatever time and culture from which it is being analysed, which would not be reading the text on its own terms. At the same time a pragmatic analysis uncovers how aspects of the text function regardless of the historical background. It is a matter of competence on behalf of the analyst to combine historical (and sociological, cultural, etc.) knowledge with a pragmatic analysis in a way that does the text justice. As I mentioned above, I distance myself from such postmodern readings which are uninterested in the original setting of the Gospel. Such readings may be privately valuable but carry little public meaning, regardless of whether the purpose is devotional or directed towards understanding the roots of Christianity from a cultural-historical perspective.

\section{Conclusion}

I have approached the first Gospel as an argument. I have done this with the help of two interrelated methods, argumentation analysis and a pragmatic literary analysis. $^{20}$ I have also indicated the valuable contributions of narrative criticism and rhetorical criticism. Together with the traditional historical-critical approach, these

\footnotetext{
19 The perlocutionary effect is the effect or consequence an illocutionary act has on the actions, thoughts, or beliefs, etc. of hearers. For instance, by arguing one may persuade or convince someone (Searle 1969, 25).

${ }^{20}$ Not all argumentation theories are pragmatic, but in the case of Pragma-Dialectics, the pragmatic aspect lies at the core of the theory, wherefore it is a most natural choice for an analysis that highlights Searlean speech acts and Gricean implicatures. Here, however, my use of Pragma-Dialectics is confined to a basic argumentation analysis in Sect. 2.4.2. For a thorough Pragma-Dialectic analysis of a New testament text I refer to my dissertation (Hietanen 2007a).
} 
methods can help us toward an interpretation that lets us better understand the purpose and function of the Gospel-story.

One purpose is for it to function as an argument in favour of the standpoint that Jesus is the Son of God, the Messiah. I have shown how the Gospel of Matthew can be seen as such an argument and how the evangelist presents different parts of the story so as to support this standpoint. The tentative argumentation structure and the example of how the story about the virgin conception can be analysed as an argument show the feasibility of an argumentation analysis. The example also shows how the literary nature of a Gospel-text makes an analysis more complex, why contextual information is crucial, and why the reader is required to invest a lot of trust in the evangelist.

Although earlier studies have noted some of the same features of Matthew, the advantage of an argumentation analysis approach is that it yields a specific description of the argumentative dimension of the text. A comparison between Kennedy's understanding of the argument in Matthew (cf. the quote on p. 5) and my exposition (cf. Table 1, p. 9) is illuminating. Taking into account the literary nature of the religious text has resulted in a different understanding of the proofs used by the evangelist. An explicit argumentation analysis approach has also enabled me to be more thorough and precise. In light of the widespread adoption of rhetorical analysis as a method in New testament exegesis, this study shows that when one from the point of view of a rhetorical analysis wants to describe argumentation (as e.g. Kennedy does), a proper argumentation analysis (i.e. one based on a theory of argumentation) should be incorporated for a clearer framework and for greater accuracy.

The same applies to the analysis of the Gadarene demoniacs. In order to explain how Matthew has designed a story such as the first exorcism in his Gospel to function as an argument, a pragmatic analysis has proven useful. Although I here only analyse one such story, it is enough to give an idea of how all stories in Matthew could be analysed similarly. Instead of giving a general idea of what is going on in the story, sophisticated tools make it possible to give detailed remarks.

In summary, my analysis shows three things. First, from a methodological point of view, when analysing argumentation, sophisticated methods make an inter-subjective critique easier also when the object is a New testament text (or, probably, any religious text for that matter). Second, that there is good reason to include argumentation analysis and literary pragmatics in the tool-box of the exegete since they help explain important features of the text and provide an important complement to narrative and rhetorical analyses. Third, that in the case of analysis of argumentation in literature, pragmatic instruments can provide a crucially better understanding of how arguments are designed than a basic argumentation analysis can.

Acknowledgements I am thankful to Dr. Agnès van Rees (Department of Speech Communication, Rhetoric and Argumentation Theory, University of Amsterdam) for feedback on earlier versions of this paper. I also greatly appreciate the many comments from the reviewers of Argumentation.

Open Access This article is distributed under the terms of the Creative Commons Attribution Noncommercial License which permits any noncommercial use, distribution, and reproduction in any medium, provided the original author(s) and source are credited. 


\section{References}

Aland, K. et al., ed. 1993. Stuttgart: Deutsche Bibelgesellschaft.

Aristotle, 1994. The 'Art' of rhetoric (trans: Freese, J.H.). Cambridge: Harvard University Press.

Chatman, S. 1978. Story and discourse: Narrative structure in fiction and film. Ithaca, NY: Cambridge University Press.

Dickson, J.P. 2005. Gospel as news: $\varepsilon v \alpha \gamma \gamma \varepsilon \lambda$-from Aristophanes to the Apostle Paul. New Testament Studies 51:212-230.

France, R.T. 1990 [1985]. The Gospel according to Matthew: An introduction and commentary (Tyndale New testament commentaries, 1). Leicester: Inter-Varsity Press.

Grice, P. 1975. Logic and conversation. In Syntax and semantics III: Speech acts, ed. P. Cole and J.L. Morgan, 41-58. London: Academic Press.

Grice, P. 1989. Studies in the way of words. Cambridge, MA \& London: Harvard University Press.

Hietanen, M. 2007a. Paul's argumentation in galatians: A pragma-dialectical analysis (Library of New Testament Studies, 344). London: T\&T Clark.

Hietanen, M. 2007b. The Gospel of Matthew as an argument. In Proceedings of the sixth conference of the international society for the study of argumentation, ed. F.H. van Eemeren, J.A. Blair, C.A. Willard, and B. Garssen, 607-613. Amsterdam: SicSat.

Howell, D.B. 1990. Matthew's inclusive story: A study in the narrative rhetoric of the first gospel (Journal for the Study of the New Testament, Supplement Series, 42). Sheffield: JSOT Press.

Jefferson, G., H. Sacks, and E. Schegloff. 1974. A simplest systematics for the organisation of turn-taking for conversation. Language 50, 696-735.

Kennedy, G.A. 1984. New Testament interpretation through rhetorical criticism (Studies in Religion). Chapel Hill \& London: University of North Carolina Press.

Kingsbury, J.D. 1988. Matthew as story. 2nd rev. edn. Philadelphia: Fortress Press.

Leech, G.N., and M.H. Short. 1981. Style in fiction: A linguistic introduction to English fictional prose. London: Longham.

Liftin, D. 1994. St. Paul's theology of proclamation: 1 Corinthians 1-4 and Greco-Roman Rhetoric (Journal for the Study of the New Testament Supplement, Manuscript Series, 79). Cambridge: Cambridge University Press.

Louw, J.P., and E. Nida, eds. 1999. Greek-English lexicon of the New Testament based on semantic domains. United bible societies. Used as part of bible windows 5.52 8/25/99. Silver mountain software.

Luz, U. 1985. Das Evangelium nach Matt häus (Mt 1-7) (Evangelisch-Katholischer Kommentar zum Neuen Testament, I/1). Zürich: Benziger Verlag.

Luz, U. 1989. Matthew 8-20: A commentary (Hermeneia). Minneapolis: Fortress Press.

Luz, U. 2005. Studies in Matthew (trans: Selle, R.). Grand Rapids, Mich \& Cambridge: Wm. B. Eerdmans Publishing Co.

New Revised Standard Version Bible: Anglicized Edition. 1995. Oxford: Oxford University Press.

Pratt, M.L. 1977. Toward a speech act theory of literary discourse. Bloomington/London: Indiana University Press.

Russell, B. 1927. Why i am not a Christian. URL: http://users.drew.edu/ jlenz/whynot.html. Accessed 20 June 2007.

Searle, J.R. 1969. Speech acts: An essay in the philosophy of language. Cambridge: Cambridge University Press.

Searle, J.R. 1975. A taxonomy of illocutionary acts. In Language, mind and knowledge, ed. K. Gunderson, 344-369. Minneapolis: University of Minnesota Press.

Searle, L. 2005. New criticism. In The John Hopkins guide to literary theory, 2nd edn, ed. M. Groden, M. Kreiswirth, and I. Szeman, 691-698. Baltimore: The John Hopkins University Press. URL: http://uwch-4.humanities.washington.edu/Texts/SEARLE/NEW\%20CRITICISM-rev.pdf. Accessed 28 Aug 2010.

van Eemeren, F.H., and R. Grootendorst. 1984. Speech acts in argumentative discussions: A theoretical model for the analysis of discussion directed towards solving conflicts of opinion (Pragmatics and Discourse Analysis, 1). Dordrecht (Holland) \& Cinnaminson (USA): Foris Publications.

van Eemeren, F.H., and R. Grootendorst. 1992. Argumentation, communication, and fallacies. Hillsdale, NJ: Lawrence Erlbaum Associates, Publishers. 
van Eemeren, F.H., R. Grootendorst, and F.S. Henkemans. 1996. Fundamentals of argumentation theory: A handbook of historical backgrounds and contemporary developments. Mahwah, NJ: Lawrence Erlbaum Associates, Publishers.

van Eemeren, F.H., R. Grootendorst, and F.S. Henkemans. 2002. Argumentation: Analysis, evaluation, presentation. Mahwah, NJ: Lawrence Erlbaum Associates, Publishers. 